\begin{tabular}{|c|c|c|}
\hline & International Journal of Current Research in & \\
\hline & $\begin{array}{c}\text { Biosciences and Plant Biology } \\
\text { ISsN: 2349-8080 }\end{array}$ & ân \\
\hline PUBLI & Journal homepage: www.ijcrbp.com & \\
\hline
\end{tabular}

\title{
Comparative Gross Morphology of Some Species of Sesamum L.
}

\author{
C. U. Aguoru' ${ }^{*}$, B. E. Okoli² and J. O. Olasan' ${ }^{1}$ \\ ${ }^{1}$ Department of Biological Sciences, University of Agriculture, Makurdi, Nigeria \\ ${ }^{2}$ Department of Plant Science and Biotechnology, University of Port Harcourt, Nigeria \\ *Corresponding author.
}

\section{A bstract}

Studies were carried out to compare the gross morphology - vegetative and floral of four species of the genus Sesamum L. occurring in Nigeria, West Tropical Africa with a view to provide information on their taxonomy, systematics, agronomic and identification traits at the early stage of their growth in the field as this has been problematic. Observations were made on fresh and herbarium specimens and records of relevant quantitative and qualitative traits taken. Appropriate statistical tools were applied to analyse quantitative traits. The results indicated variations strong enough to separate the taxa even at specific level. Similarities also exist that suggest they are still remaining together in a genus. Lower/early leaves separate them at species level. $S$. indicum-cordate, S. angustifolium-lanceolate, S. radiatum-ovate and S. alatum-oblong and identification at early stage of growth without flowers is possible. This information is available for the first time. The beak shape of capsules separates the taxa at specific levels. S. angustifolium-narrow oblong, $S$. indicum-broad oblong, S. Radiatum-square; whereas $S$. alatum has tapered apex. The seeds also aid in identifying Sesamum species: $S$. angustifolium-radially rough, $S$. indicum-smooth, $S$. radiatum-reticulately rough whereas $S$. alatum partially rough and winged. Dimensions of internode length, seed sizes and number of seeds per capsule, capsule length, beak length, and leaf dimensions separate the taxa at species level. Similarities which also suggest togetherness in same genus were identified and several documented for the first time.
\end{abstract}

\section{Article Info}

Accepted: 07 April 2016

Available Online: 06 May 2016

\section{Ke ywords}

Gross morphology

Plant systematics

Sesamum species

\section{Introduction}

Sesamum L. is a neglected genus (IPGRI, 2004) of the subfamily Asterideae, Family- Pedaliaceae, OrderScrophulariales (Khidir , 1978). There is controversy on number of species in the genus (19-20 species) (Bedigian, 1984; Aguoru et al., 2014) with controversial taxonomy (Busari et al., 2005). All species in genus are believed to be of African origin (Nayar, 1995) but spread through western Asia to India where secondary centres of diversity exist (Khidir, 1978; Bedigian, 1984; Busari et al., 2005; Bedigian, 1988; 2003a; 2003b; 2004; Bedigian, 1985; Bedigian et al., 1985; Bedigian et al., 1986).
Sesamum was taken to new world along slave routes and established both in Brazil and southern Carolina USA (Khidir, 1978; Bedigian, 2006; Bedigian et al., 1986). The genus is represented in Nigeria by 4 species (Hutchinson and Dalziel 1958; Aguoru et al., 2014). Medicinally and nutritionally the leaves, seeds and seed coats of the species are very rich in essential oils; amino acids; calcium etc (Brar and Ahuja, 1979; Kamal-Eldin, 1993; Johnson et al., 1979). Nigeria is ranked the 6th worlds' largest producer, 75,000MT annually of $S$. indicum a species in the genus coming from small family farm holders (FAO, 2004). Early identification of species in the field is difficult (Aguoru et al., 2014). 
Aguoru et al. (2014) also worked on the phytogeography of the various species in Nigeria establishing their locations. All taxonomic/systematic controversies are resolved using several lines of evidence, gross morphology being the most important (Radford, 1986; Aguoru and Okoli, 2012). This work was therefore set to use all the morphological evidences, vegetative and floral to separate the species of Sesamum L. found in Nigeria and also to make the identification of species easy at the early stage of growth which hitherto was not possible.

\section{Materials and methods}

This was done after Radford (1986), IPGRI and NBPGR (2004) and Aguoru and Okoli (2008). Observations on vegetative and floral characteristics of the Sesamum L. species were made on mature plants growing in the field or on identified and preserved materials deposited in the various herbaria consulted (FHI, UPH, UAM, BUK, UI, IFE). Living plants growing in the wild, farms, roadside, abandoned farm lands near residential buildings, in garden at Bayero University Biological Sciences Kano and various other places visited were examined. Photographs and drawings of relevant morphological features were taken or made. The floral diagram and formulae of the taxa were constructed. Measurements of the various morphological features were made. Various statistical tools relevant were used for the analysis of quantitative characters. A statistical kit SPSS was used. SHARP advanced D.A.L calculator was also used. Table 1 displays list of materials examined with locations of collection, collectors/herbarium number and date of collection for each species of Sesamum.

Table 1. Sources of Sesamum L. species examined.

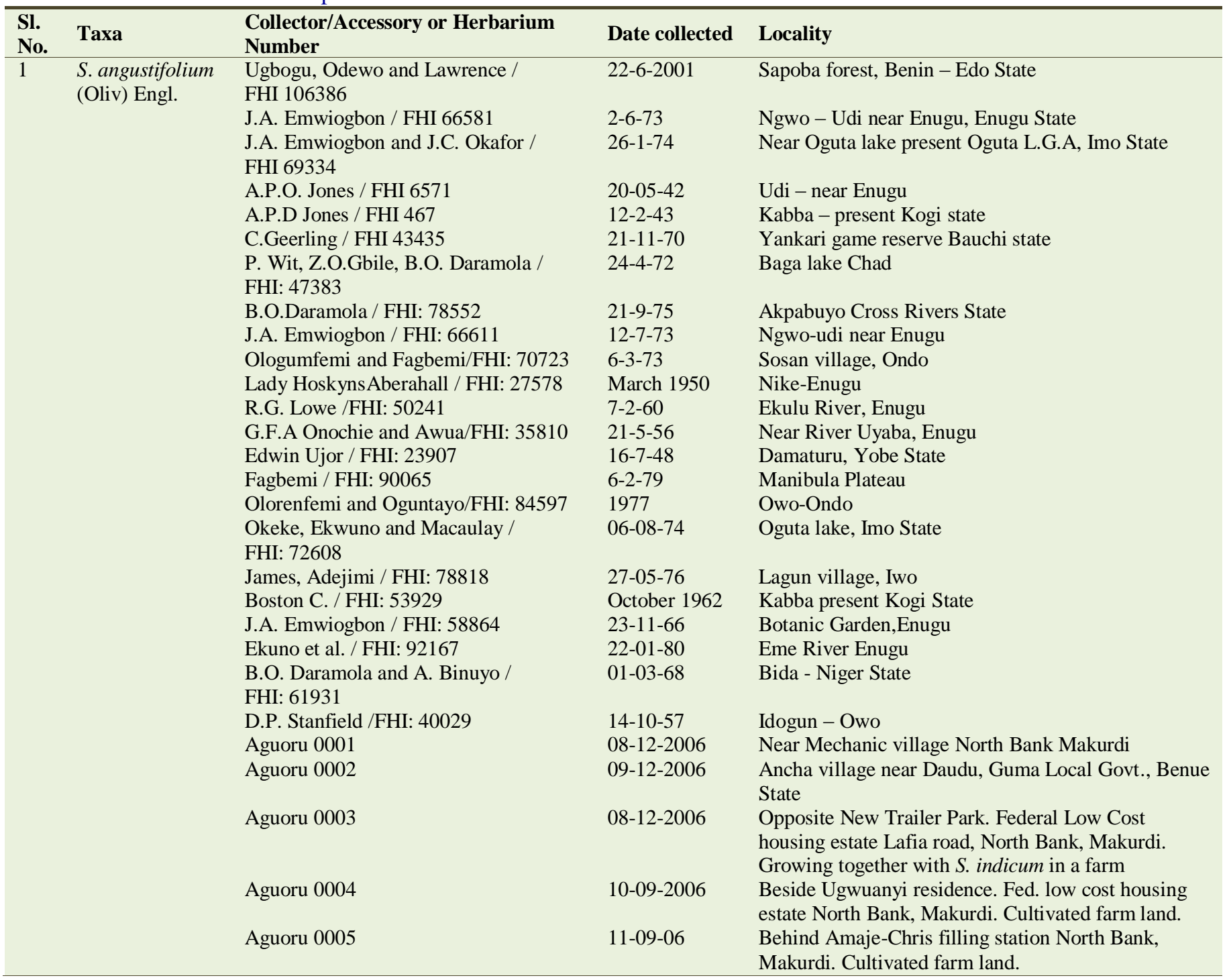




\begin{tabular}{|c|c|c|c|c|}
\hline $\begin{array}{l}\text { Sl. } \\
\text { No. }\end{array}$ & Taxa & $\begin{array}{l}\text { Collector/Accessory or Herbarium } \\
\text { Number }\end{array}$ & Date collected & Locality \\
\hline \multirow{39}{*}{2} & \multirow{39}{*}{ S. indicum $\mathrm{L}$. } & Aguoru 0008 & $18-12-06$ & Ankpa Quarters Road cemetery \\
\hline & & Aguoru 0009 & $29-12-06$ & Apir Mechanic village Makurdi \\
\hline & & Aguoru 0010 & $11-10-2007$ & Roadside along Ayangba road AnkpaKogi State \\
\hline & & Aguoru 0013 & $10-07-07$ & $\begin{array}{l}\text { Near Upa's compound Udei village Guma LGA } \\
\text { Benue State. }\end{array}$ \\
\hline & & Aguoru 0048 & $20-07-08$ & $\begin{array}{l}\text { Gbajimba Rd near University of Agriculture. } \\
\text { Experimental Farm }\end{array}$ \\
\hline & & Aguoru 0049 & 31-08-08 & Federal low cost housing estate Lafia road, Makurdi. \\
\hline & & $\begin{array}{l}\text { H.D. Onyeachusim and M.G. Latilo / } \\
\text { FHI: } 54065\end{array}$ & $21-2-1964$ & Osomba village, Oban \\
\hline & & Olorunfemi et al. / FHI: 93371 & 02-09-1980 & Aiyede, Ekiti \\
\hline & & M.O. Ayaji / FHI: 26955 & $29-06-1950$ & Oni - Gambari \\
\hline & & S.O. Magaji /FHI: 27261 & $25-01-1968$ & Okene - Oguda Rd. \\
\hline & & Odewo and Binuyo /FHI: 96216 & $11-08-1981$ & Mokwa \\
\hline & & Eimunjeze et al. / FHI: 66504 & $20-05-1973$ & Keffi \\
\hline & & J.O. Chapman / FHI: 46246 & $28-06-1972$ & Mambilla, Plateau \\
\hline & & $\begin{array}{l}\text { Daramola B.O. and M. Okoro / } \\
\text { FHI: } 99037\end{array}$ & 02-11-1982 & Abuja \\
\hline & & B.O. Daramola /FHI: 84513 & 23-08-1977 & Gembu - Janro - Umaru Camp. \\
\hline & & B.O. Daramola /FHI: 105098 & $30-07-1993$ & Bauchi \\
\hline & & Odewo et al. / FHI: 88121 & $25-10-1978$ & Badagry \\
\hline & & Eimunjeze and Oguntayo / FHI: 70206 & $16-05-1974$ & $\begin{array}{l}\text { Iguoriakhi } \\
\text { Benin Edo }\end{array}$ \\
\hline & & T.K. Odewo / FHI: 87861 & $28-08-1977$ & Njawai, Gembu, Mambilla Plateau \\
\hline & & Zac O. Gbile / FHI: 80930 & $17-06-1977$ & Ejigbo - Oyo \\
\hline & & Magbagbeola et al. / FHI: 94659 & 23-04-1981 & Orile-Ibara, Abeokuta \\
\hline & & Magbagheola et al. / FHI: 94927 & 22-06-1981 & Badagry - Lagos \\
\hline & & Magbagheola et al. / FHI: 94745 & 26-06-1980 & Ijebu, Ajebandele Forest Reserve \\
\hline & & Jones / FHI: 7178 & $30-12-1943$ & Oyo Ibadan \\
\hline & & J.C. Okafor and Omiyale / FHI: 62248 & 08-07-1966 & Abakaliki \\
\hline & & C.F.A. Onochie /FHI: 40229 & $23-06-1958$ & Gulu Village Badeggi - Lapai Road \\
\hline & & M.C. Ejiofor / FHI: 19849 & $21-06-1960$ & U.I. Premises Ibadan \\
\hline & & Odewo and Adedeji / FHI: 96917 & $14-12-1981$ & Gombe - Yola Road \\
\hline & & Daramola and Ihe/ FHI: 86372 & $15-05-1978$ & Ipe- Ikun Road; Ikare \\
\hline & & Ariwoado /FHI: 89201 & 08-07-1978 & Utugwang, Obudu \\
\hline & & Aguoru 0015 & $26-12-06$ & $\begin{array}{l}\text { Railway Bypass opposite NYSC State Secretariat, } \\
\text { Makurdi }\end{array}$ \\
\hline & & Aguoru 0016 & $26-12-06$ & Near General Hospital NASME N/Bank, Makurdi \\
\hline & & Aguoru 0017 & $29-12-6$ & $\begin{array}{l}\text { Beside ECWA Secondary school North Bank, } \\
\text { Makurdi }\end{array}$ \\
\hline & & Aguoru 0018 & $29-12-06$ & Opposite O.O. Obu North Bank, Makurdi \\
\hline & & Aguoru 0019 & $29-12-06$ & Ancha Village near Daudu Benue State \\
\hline & & Aguoru 0020 & $03-02-07$ & Former Agan Toll Gate Makurdi \\
\hline & & Aguoru 0021 & $03-02-07$ & Beside 'C' Division Police Makurdi \\
\hline & & Aguoru 0022 & 07-07-07 & Besides BENKOS Hotel Uniagric Road, Makurdi \\
\hline & & Aguoru 0023 & 07-07-07 & Beside TerGuma'scpd Makurdi \\
\hline
\end{tabular}




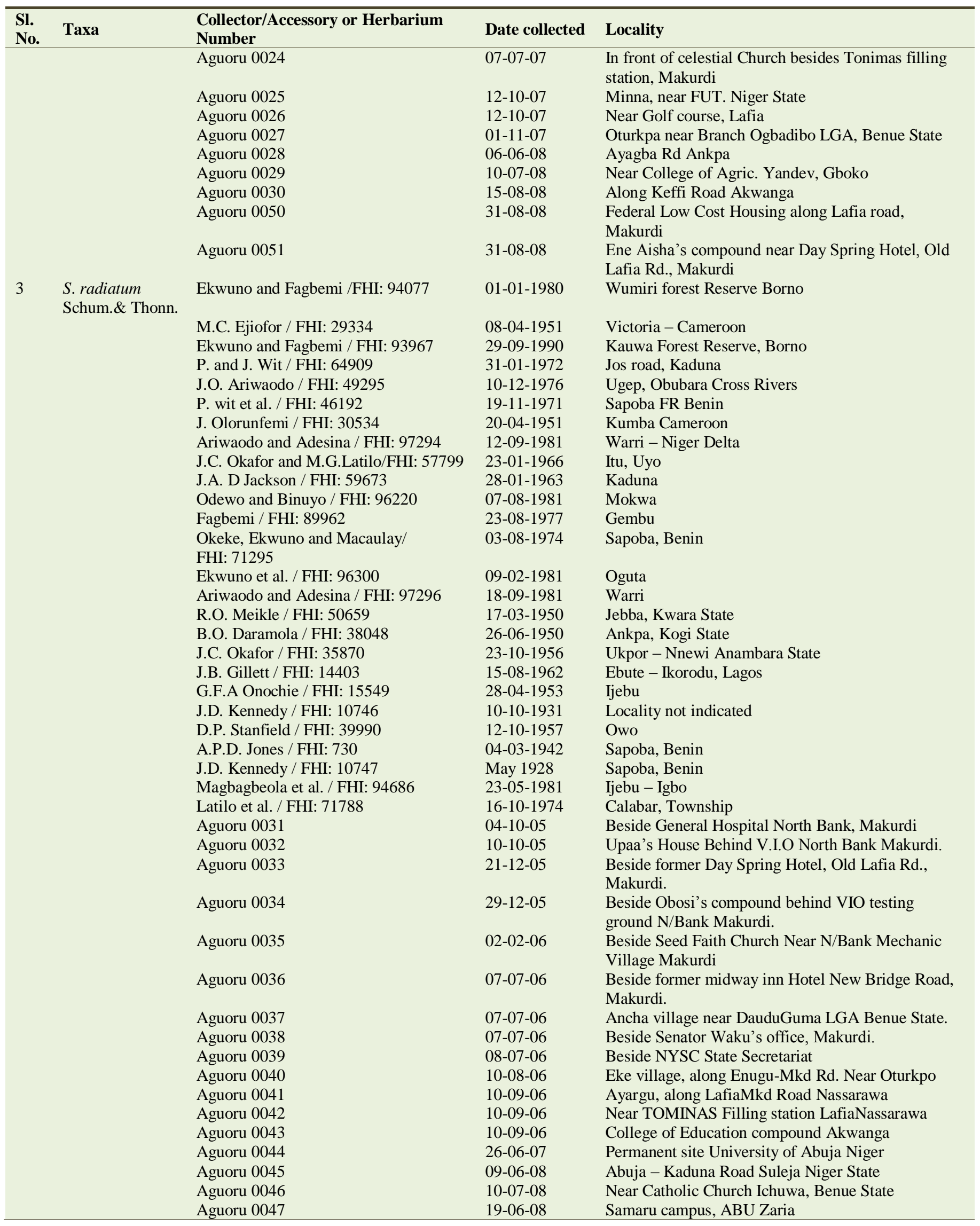




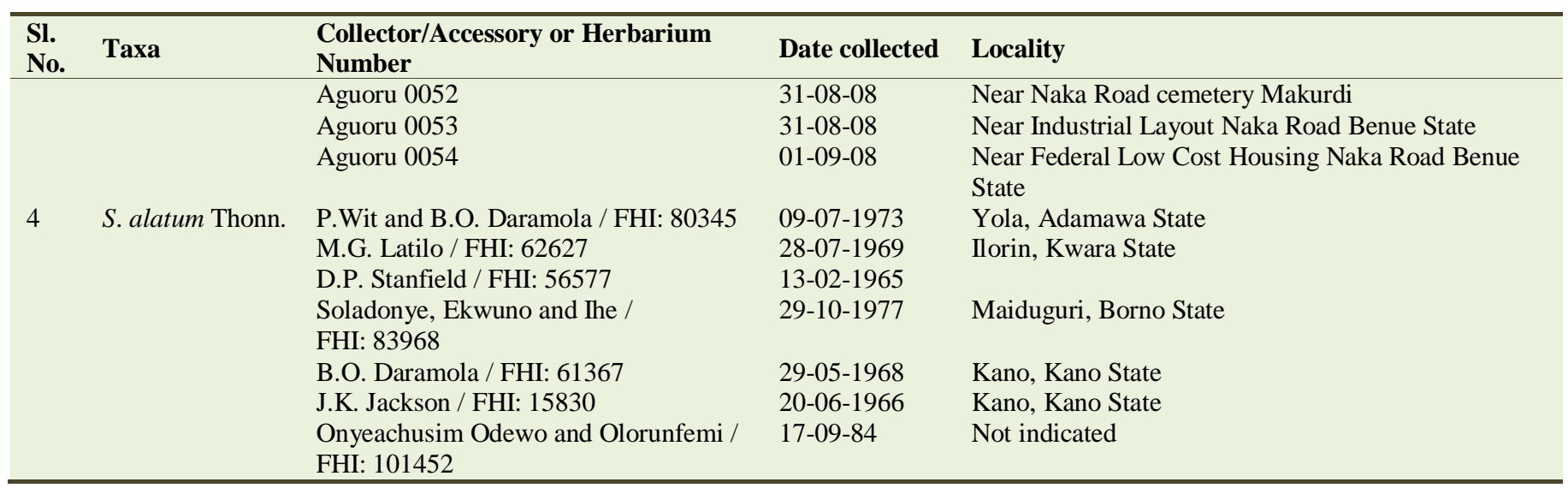

\section{Results and discussion}

Gross morphological evidences have been exploited in the delimitation of taxa at various levels and times (Aguoru and Okoli, 2008; Bedigian, 2006; Aguoru, 2009). The gross morphological features of the Sesamum species displayed enormous variations that could be applied in strengthening their delimitation at the specific levels and provide agronomic information and early identification in the field. Table 1 displays the sources of the Sesamum species examined indicating location and dates of collection, collectors and accession numbers with the various herbaria visited. Table 2 lays out the gross morphological features; vegetative and floral of the Sesamum species occurring in Nigeria. These were obtained from both fresh and herbarium materials. Figs.1a and $1 \mathrm{~b}$ show floral diagram and formulae of the species in this work respectively. Florally they are zygomorphic and hermaphroditic, ovary is superior. Figs. $2 \mathrm{a}-2 \mathrm{~d}$ show gross morphological features of Sesamum species studied.
Fig. 3 depicts the nature of the lower leaves of the Sesamum species. Fig. 4 shows variations in the nature of beaks of capsules of the various Sesamum species investigated which separates the species and affirms treatment as separate species whereas Fig. 5 shows the shape of seeds and surface architecture of seeds obtained from the various Sesamum species. All the species are annuals with $S$. angustifolium sometimes surviving to a second year with the aid of underground stumps. Their stems have 4 angles and 4 furrows and affirm inclusion in same genus. Leaves of $S$. angustifolium are cup shaped, S. indicum parted, S. radiatum trifoliate and $\mathrm{S}$. alatum islanceolate, these agrees their separation and treatment as separate species. All have simple leaves in general. General dimensions of leaves, petiole, stem, internode as shown by their means on Table 2 separate the species. Presence and exstipulate nature of glands indicate taxonomic relatedness. Shape of lower leaves separate the species taxonomically, S. indicum is concave, S. angustifolium is subovate, S. alatum is lanceolate whereas $S$. radiatum is ovate.

Table 2. Summary of morphological, macro-morphometric and Micro-morphometric characters of the Sesamum species studied.

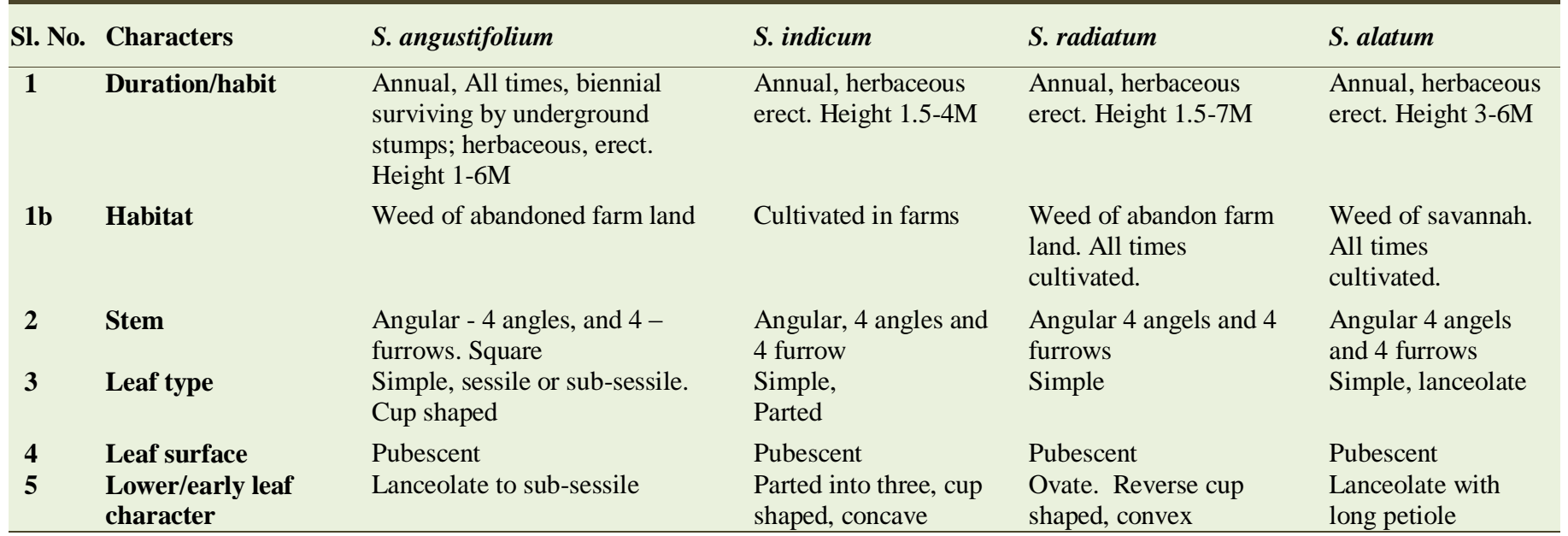




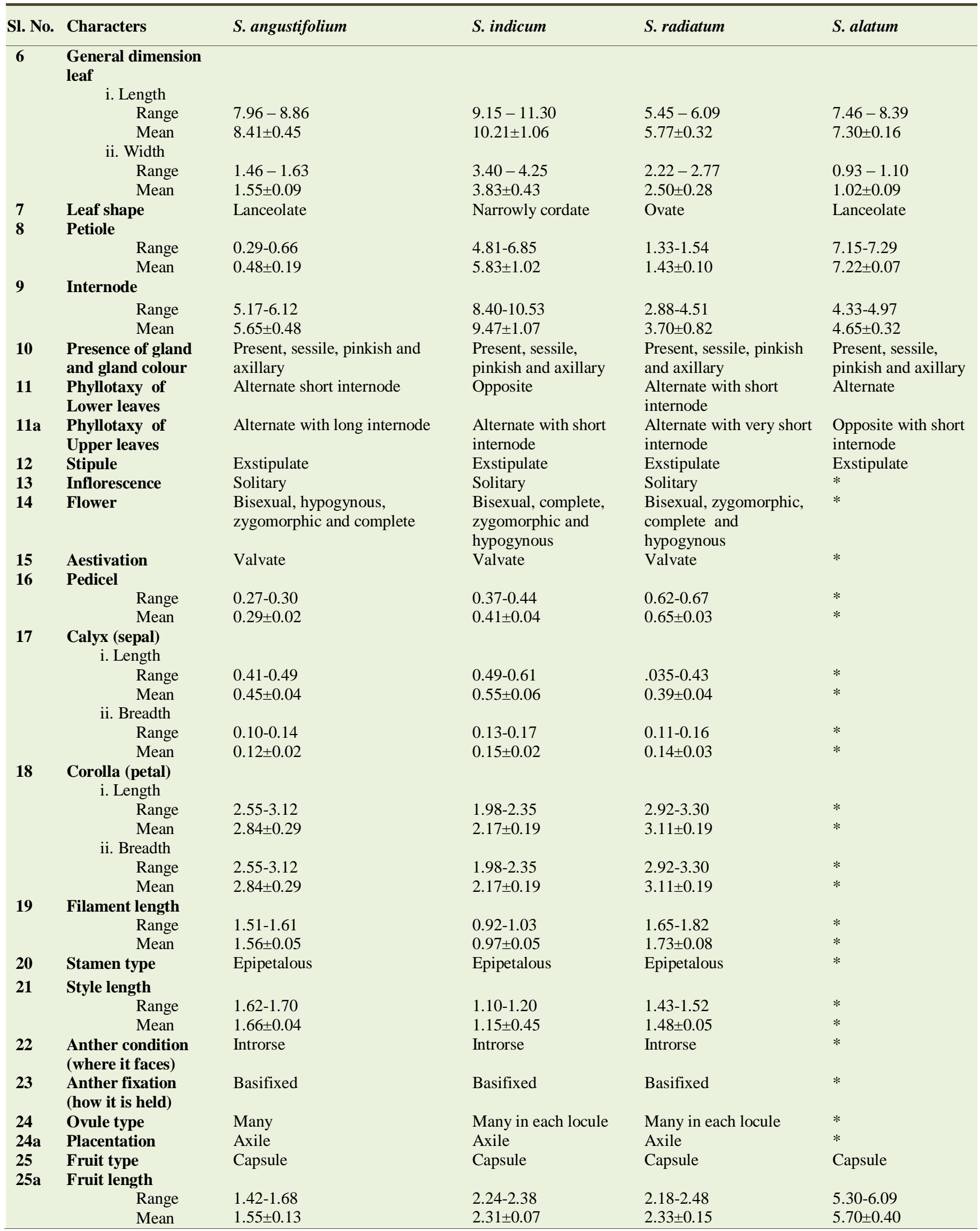




\begin{tabular}{|c|c|c|c|c|c|}
\hline Sl. No. & Characters & S. angustifolium & S. indicum & S. radiatum & S. alatum \\
\hline $25 b$ & Range & $0.30-0.33$ & $0.46-2.32$ & $0.47-0.50$ & $0.73-0.79$ \\
\hline \multirow[t]{3}{*}{26} & Beak length & & & & \\
\hline & Range & $0.16-0.19$ & $0.29-0.30$ & $0.10-0.10$ & $0.91-1.04$ \\
\hline & Mean & $0.18 \pm 0.02$ & $0.30 \pm 0.01$ & 0.10 & $0.98 \pm 0.07$ \\
\hline & & blackish in colour & $\begin{array}{l}\text { sides, whitish in } \\
\text { colour }\end{array}$ & colour & brownish in colour. \\
\hline \multirow{4}{*}{$\begin{array}{c}29 \\
\mathbf{3 0}\end{array}$} & Seed architecture & Radially rough & Smooth & Reticulately rough & Partially rough \\
\hline & Seed length & & & & \\
\hline & Range & $0.11-0.16$ & 0.30 & $0.24-0.28$ & $0.22-0.27$ \\
\hline & Mean & $0.14 \pm 0.03$ & 0.30 & $0.26 \pm 0.02$ & $0.25 \pm 0.03$ \\
\hline 33 & Root system type & Tap & Tap & Tap & $*$ \\
\hline \multirow[t]{3}{*}{34} & $\begin{array}{l}\text { Number of seeds } \\
\text { per capsule }\end{array}$ & & & & \\
\hline & Range & $86-96$ & $64-76$ & $54-68$ & $*$ \\
\hline & Mean & $91 \pm 5.0$ & $70.00 \pm 6.0$ & $60.00 \pm 6.0$ & $*$ \\
\hline
\end{tabular}

* Indicates herbarium material was used and attribute could not be measured/ correctly observed.
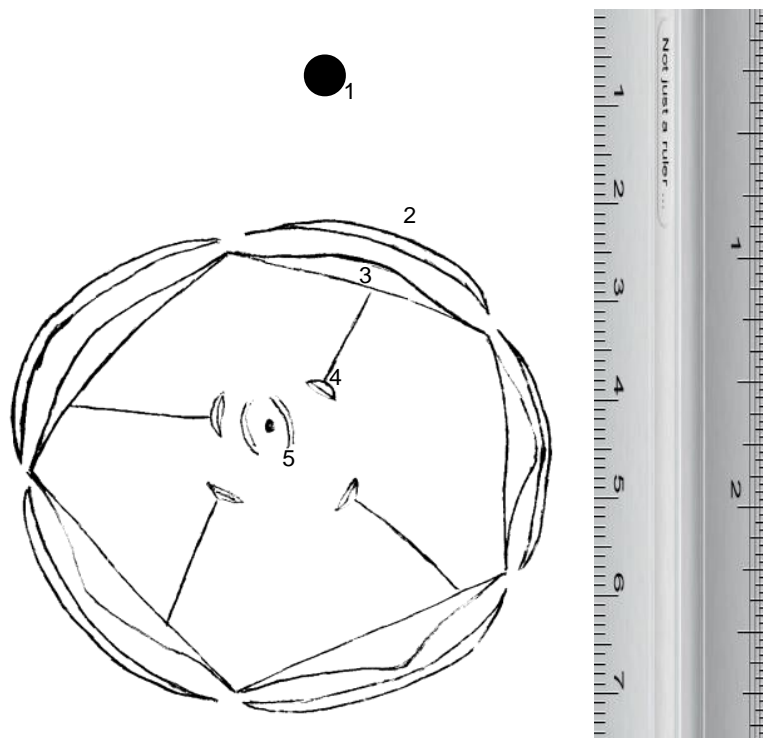

Fig. 1a: The floral diagram of the genus Sesamum (X3). 1- Main axis; 2-Calyx or Sepals; 3-Petals or Corolla; 4: Androecium; 5: Gynoecium.

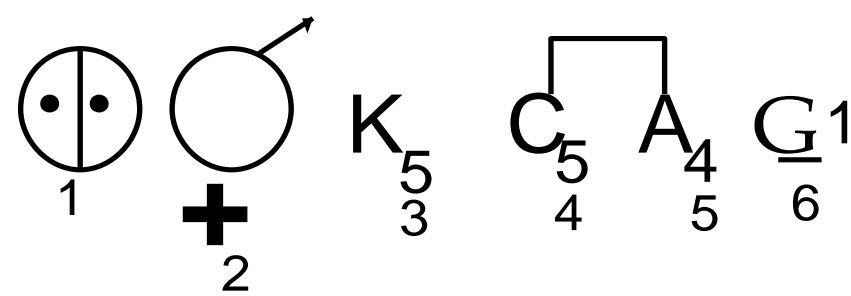

Fig. 1b: The floral formula of the genus Sesamum. 1-Symmetry (Zygomorphism); 2-Hermaphroditism; 3-Calyx (5); 4-Petals (5); 5Androecium (4) attached to petals; 6: Gynoecium (1) with superior Ovary. 

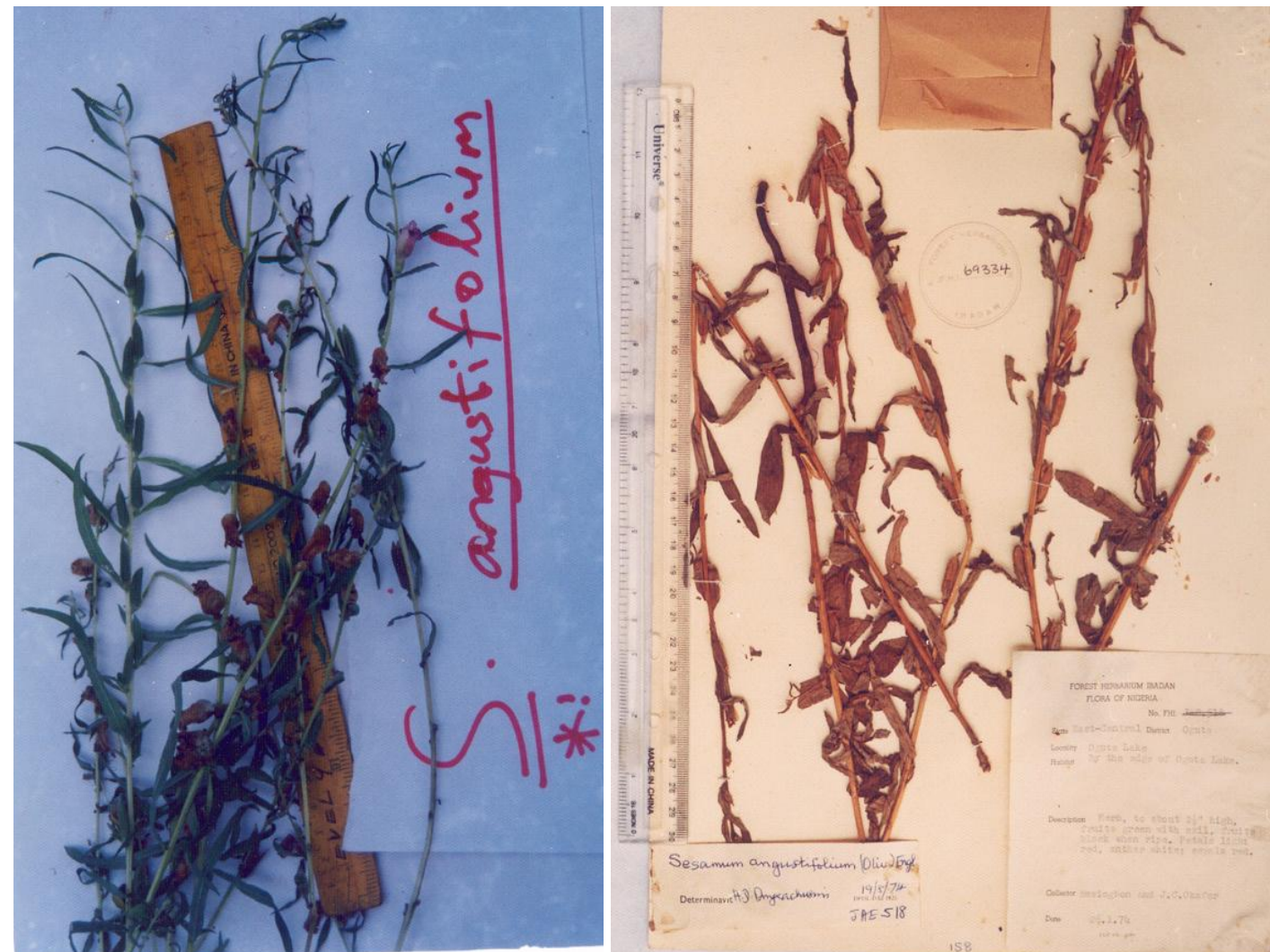

Fig. 2a: S. angustifolium (Fresh and herbarium specimens).
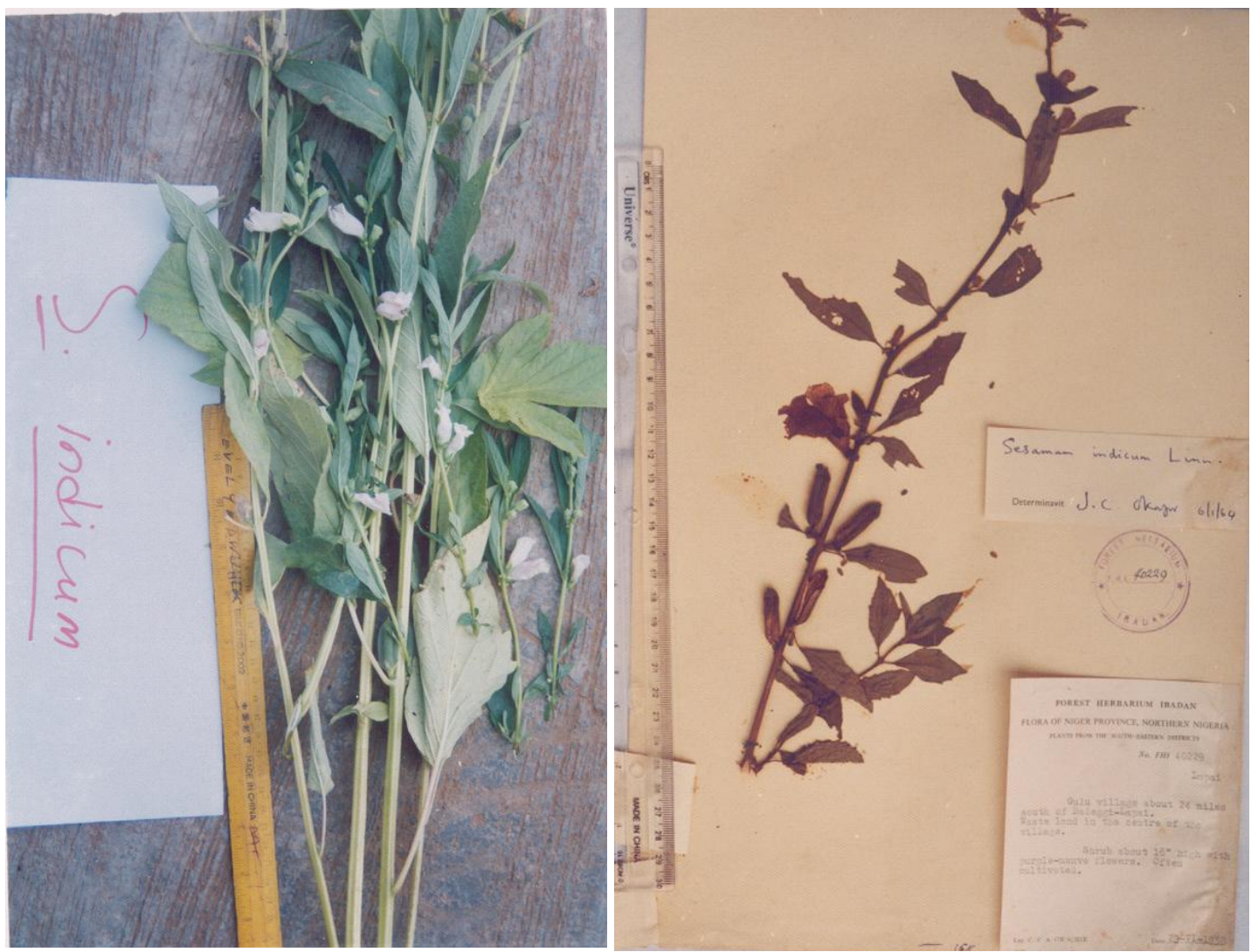

Fig. 2b: S. indicum (Fresh and herbarium specimens). 


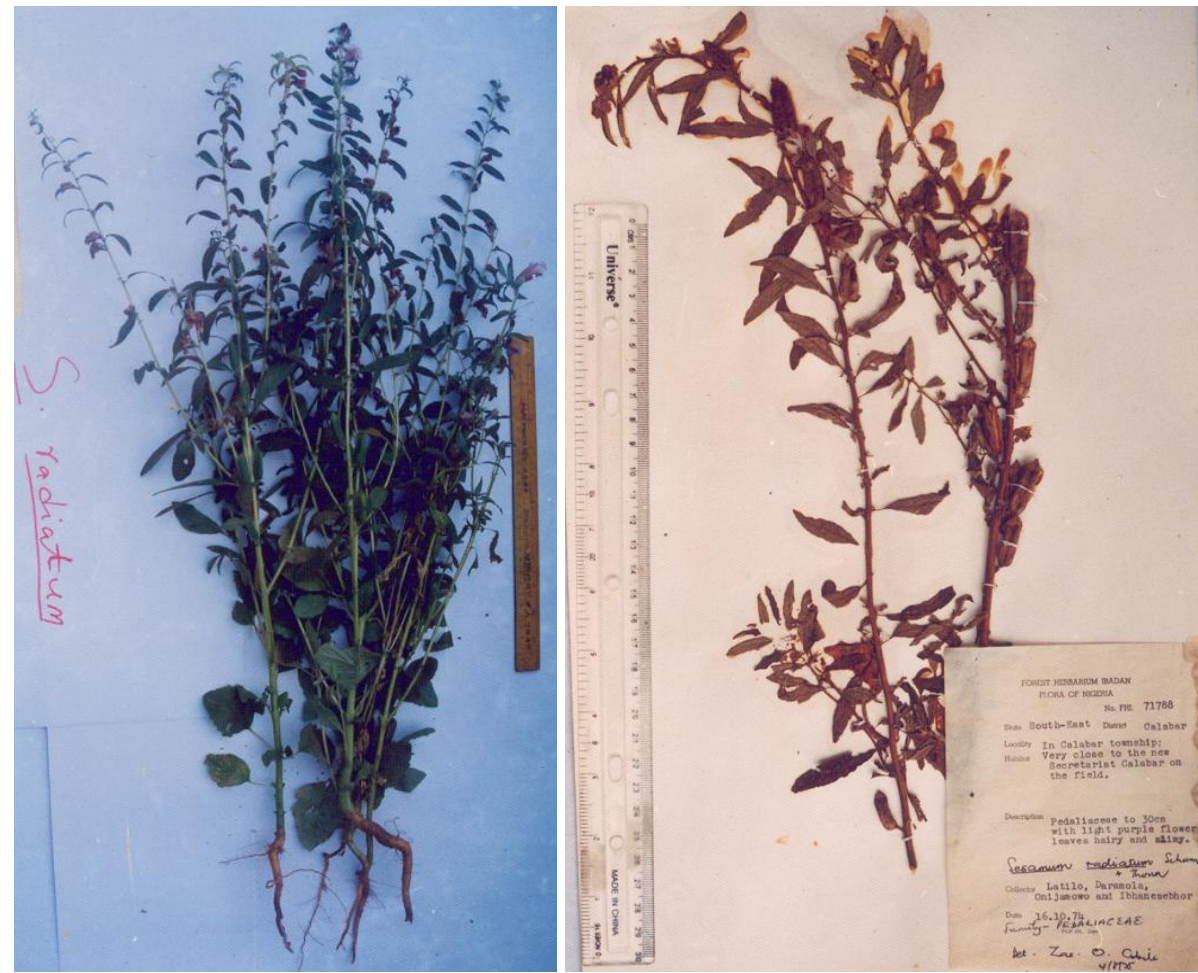

Fig. 2c: S. radiatum (Fresh and herbarium specimens).

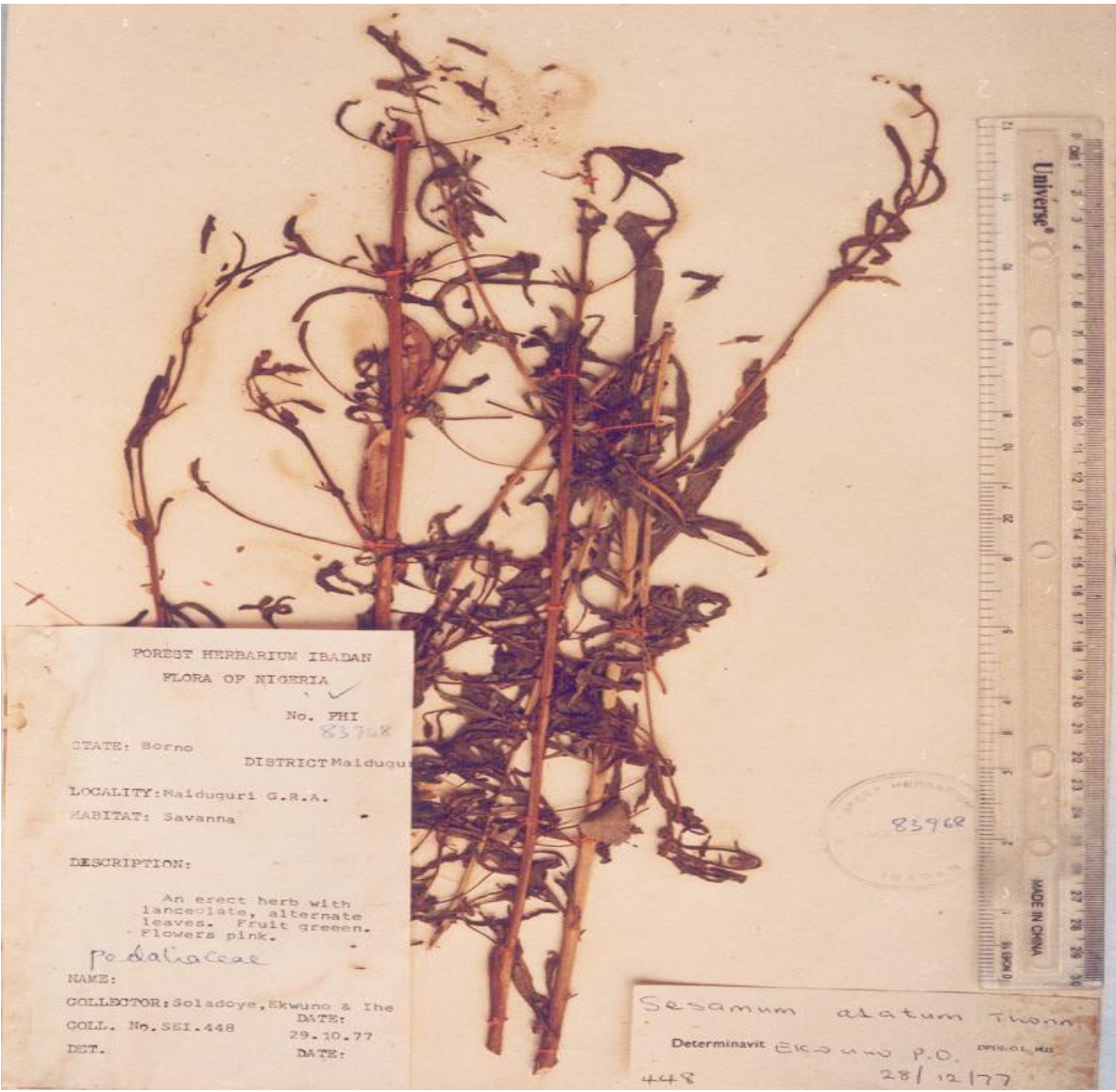

Fig 2d: S. alatum (Herbarium specimen). 


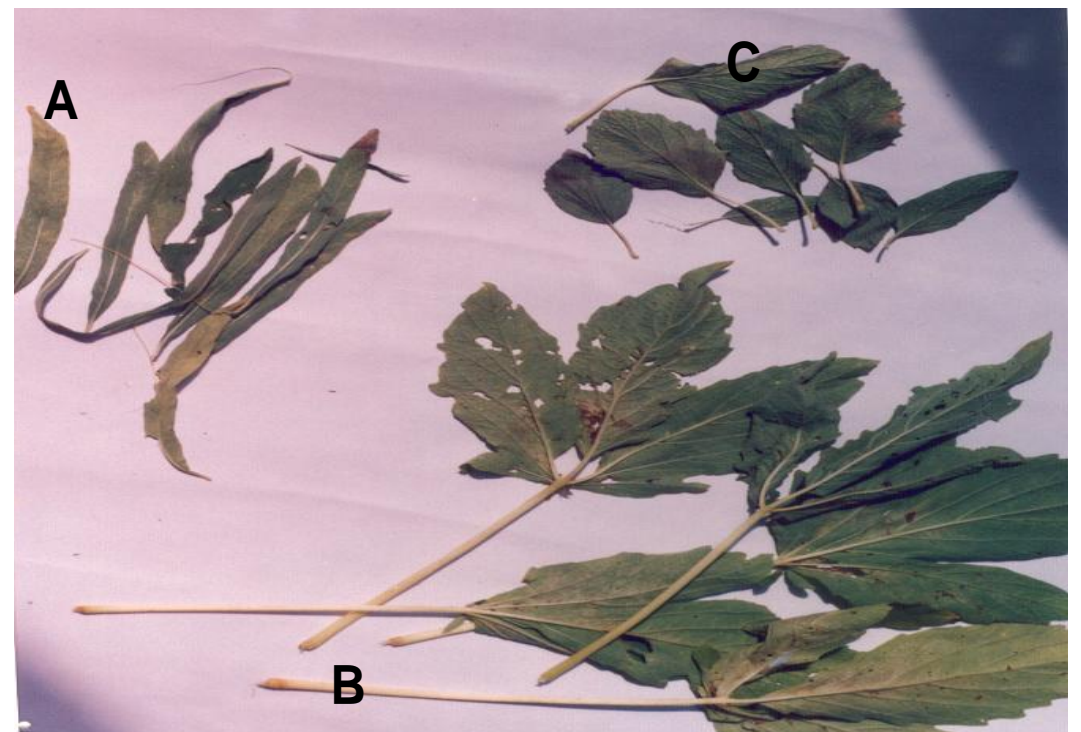

Fig. 3: A. Sesamum angustifolium-lanceolate; B. Sesamum indicum-trifoliate and ovate; C. Sesamum radiatum - cordate.

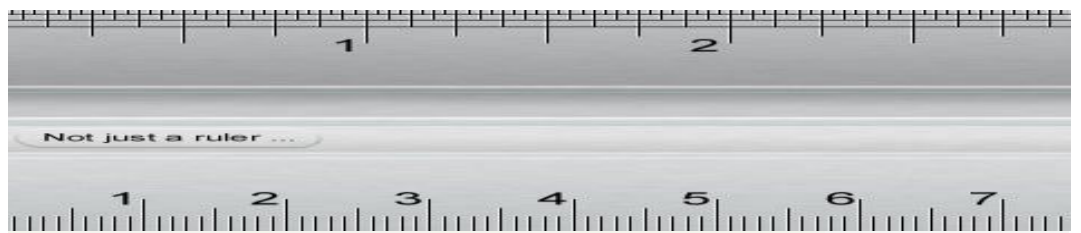

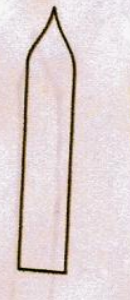

A

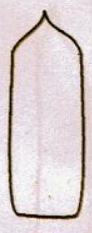

B

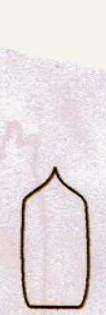

C

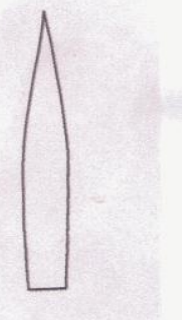

D

Fig. 4: The shape of beaks on capsule of each species (X3). A = S. angustifolium - narrow oblong; B $=S$. indicum - broad oblong; $\mathrm{C}=S$. radiatum - square; $\mathrm{D}=S$. alatum - tapered at apex (adapted from IPGRI and NBPGR, 2004 with modifications).

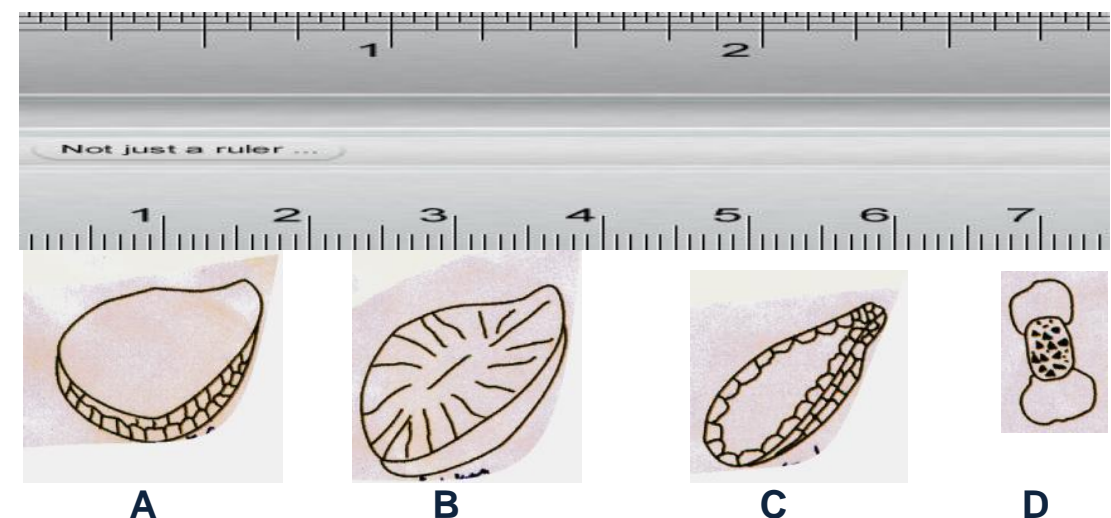

Fig. 5: The seed shapes of the Sesamum species studied (X4). A $=$ S. angustifolium $=$ oval with concave sides; $\mathrm{B}=S$. indicum $=$ oval with convex sides; $\mathrm{C}=S$. radiatum $=$ elongated; $\mathrm{D}=$ S.alatum $=$ winged (adapted from IPGRI and NBPGR, 2004 with major modifications). 
An indented taxonomic (diagnostic) key based on the morphological attributes of the species investigated in this study is presented below.

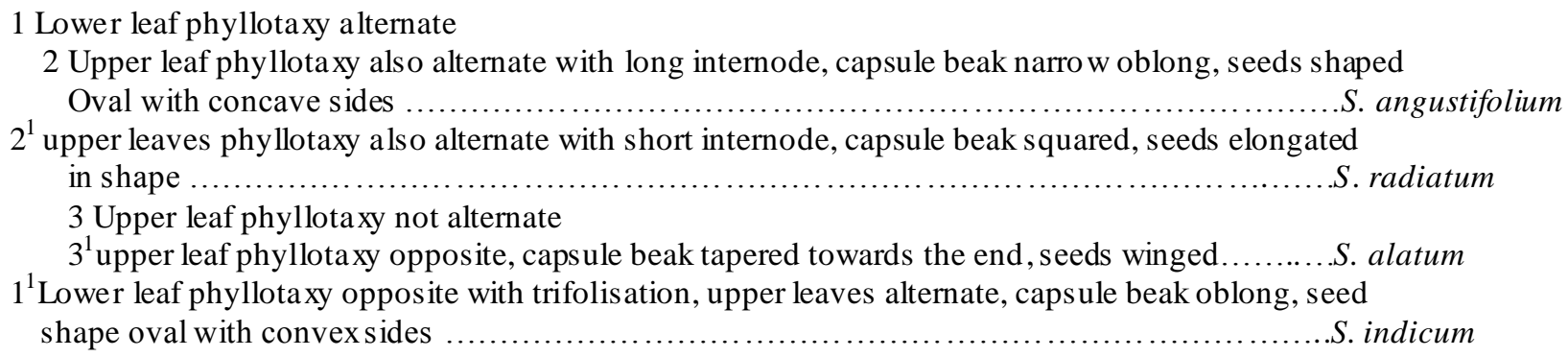

\section{Conflict of interest statement}

Authors declare that they have no conflict of interest.

\section{References}

Aguoru, C. U., Okoli, B. E., 2008. Observations on the vegetative and floral morphology of some Momordica species (Cucurbitaceae) in tropical western Africa. Int. Sci. Res. J. 1(2), 146-150.

Aguoru, C. U., Okoli, B. E., 2012. Comparative stem and petiole anatomy of West African species of Momordica L. (Cucurbitacea). Afr. J. Plant Sci. 6(15), 403-409.

Aguoru, C. U., 2009. Biosystematics Studies on the Genus Sesamum L. in Nigeria. PhD thesis, Department of Plant Science and Biotechnology, University of Port Harcourt, Nigeria.

Aguoru, C. U., Okoli, B. E., Olasan, J. O., 2014. Phytogeography of the genus Sesamum L. (Pedaliaceae) in Nigeria, West Tropical Africa. Scient. J. Crop Sci. 3(11), $115-122$.

Bedigian, D., 1984. Sesamum indicum L. Crop Origin, Chemistry and Ethnobotany. PhD thesis, University of Illinois, Urban-Champaign.

Bedigian, D., 1985. Isie-gisSesam or flax? Bull. Sumer. Agric. $2,159-178$

Bedigian, D., 1988. Sesamum indicum L. (Pedaliaceae): Ethnobotany in Sudan, crop diversity, lignans, origin and related taxa. In: Modern Systematic Studies in African Botany (Eds.: Goldblatt, P., Lowry, P. P.). Proceedings of the Eleventh Plenary Meeting of the Association for the Taxonomic Study of the Flora of Tropical Africa at the Missouri Botanical Garden, St. Louis, June 10-14, 1985. Monogr. Syst. Bot. Missouri Bot. Gard. 25. pp.315-321.

Bedigian, D., 2003a. Evolution of Sesame revisited: Domestication, diversity and prospects. Genet. Resour. Crop Evol. 50, 779-787.

Bedigian, D., 2003b. Sesame in Africa: Origin and dispersals. In: Food, Fuel and Fields - Progress in African Archaeobotany (Eds.: Neumann, K., Butler, A., Kahlheber, S.). Africa Praehistorica. Heinrich- BarthInstitute, Cologne. pp.17-36.
Bedigian, D., 2004. History and lore of sesame in south west Asia. Econ. Bot. 58(3), 329-353.

Bedigian, D., 2006. Assessment of sesame and its wild relatives in Africa. In: Taxonomy and Ecology of African Plants, their Conservation and Suitable Use (Eds.: Ghazanfar, S.A., Beentje, H. J.). Royal Botanic Gardens, Kew. pp.481-491.

Bedigian, D., Seigler, D. S., Harlan, J. R., 1985. Sesamin, sesamolin and the origin of sesame. Biochem. Syst. Ecol. 13, 133-139.

Brar, G.S., Ahuja, K.L., 1979. Sesame: its culture, genetics, breeding and biochemistry. in Annual Review of Plant Science (Ed.: Malik, C.P.). Kalyani Publishers, New Delhi. pp.245-303.

Busari, L. D., Olowe, V. I. O., Idowu, A. A., 2005. Sesame. In: Major Legumes and Oil-Seeds of Nigeria: Principles of Production and Utilization (Eds.: Idem, N.U.A., Showemimo, F.A.). Institute for Agricultural Research, ABU Zaria, Nigeria. pp.136-167.

FAOSTAT Data, 2004.http://apps.fao.org/faostat/ collections? version $=$ ext $\&$ hasbulk $=0 \&$ subset=agriculture (retrieved on March 2005).

Hutchinson, J., Daziel, J.M., 1958. Flora of West Africa. Vol. I, Part 2. $2^{\text {nd }}$ Edn. Crown Agents for Overseas Governments and Administration, Mill Bank, London Sw. 1. pp.567-569.

IPGRI and NBPGR, 2004. Descriptors for Sesame (Sesamum spp.). International Plant Genetic Resources Institute, Rome, Italy and National Bureau of Plant Genetic Resources, New Delhi, India.

Johnson, L.A., Suleiman, T.M., Lusas, E.W., 1979. Sesame protein: A review and prospectus. J. Amer. Oil Chem. Soc. 56, 463-468.

Kamal-Eldin, A., 1993. Seed oils of Sesamum indicum L. and some wild relatives. A compositional study of the fatty acids, acyl lipids, sterols, tocopherols and lignans. Ph.D. thesis, Swedish University of Agricultural Sciences, Uppsala.

Khidir, M. O., 1978. Oil seeds (Sesame). Crop genetic resources in Africa. Proceedings of workshop jointly organized by association for the advancement of agricultural science in Africa and IITA, Ibadan, Nigeria. pp.92-102. 
Nayar, N.M., 1995. Sesame, Sesamum indicum L. (Pedaliaceae). in Evolution of Crop Plants. $2^{\text {nd }}$ Edn. (Eds.: Smartt, J., Simmonds, N. W.). Wiley, New York. pp.404407.
Radford, A. E., 1986. Fundamentals of Plant Systematics. Harper and Row Publishers, New York, USA. 498p.

\section{How to cite this article:}

Aguoru, C. U., Okoli, B. E., Olasan1, J. O., 2016. Comparative gross morphology of some species of Sesamum L. Int. J. Curr. Res. Biosci. Plant Biol. 3(5), 21-32.

doi: http://dx.doi.org/10.20546/ijcrbp.2016.305.004 